\title{
UPAYA MENINGKATKAN HASIL BELAJAR MATEMATIKA DENGAN MENGGUNAKAN MODEL PEMBELAJARAN KOOPERATIF TIPE NUMBER HEAD TOGETHER (NHT) KELAS IV SD N 101212 PADANG BUJUR
}

\author{
Yulia Anita Siregar \\ Program Studi Pendidikan Matematika \\ Universitas Muhammadiyah Tapanuli Selatan \\ yulia_regar@yahoo.co.id
}

\begin{abstract}
This study aims to improve the learning outcomes of Mathematics students in grade IV SD N 101212 Padang Bujur. This study uses Classroom Action Research (CAR) type of collaboration with steps of planning, action, observation, and reflection consisting of two cycles. Data collection techniques used are test, non-test, and documentation. Adapaun indicator of success of this study is $85 \%$ of all students got a value of $\geq 75$. The results of the study were analyzed by completeness analysis. In the teaching and learning process using the cooperative type NHT learning model, in cycles 1 and 2 Mathematics learning outcomes increased. Of the students with 15 children, when the pre-cycle students were completed there were $5(33.33 \%)$. Whereas 10 students $(66.66 \%)$ did not complete. After conducting classroom action research using the NHT cooperative learning model in the first cycle the students who completed the study numbered 8 students $(53.33 \%)$ while the incomplete ones in the study were 7 students with an average score of 73.66. In the second cycle, students who completed learning were 13 students (86.66\%), while those who did not complete the study were 2 students $(13.33 \%)$ with an average score of 81.33 . The results of this study indicate that through the NHT cooperative learning model can improve Mathematics learning outcomes for students in Class IV SD N 101212 Padang Bujur.
\end{abstract}

Keywords: Cooperative learning model Number Head Together (NHT) type, Mathematics Learning Outcomes

\begin{abstract}
Abstrak. Penelitian ini bertujuan untuk meningkatkan hasil belajar Matematika siswa kelas IV SD N 101212 Padang Bujur. Penelitian ini menggunakan Penelitian Tindakan Kelas (PTK) jenis kolaborasi dengan langkah perencanaan, tindakan, observasi, dan refleksi yang terdiri dari dua siklus. Teknik pengumpulan data yang digunakan yaitu tes, non tes, dan dokumentasi. Adapaun indikator keberhasilan dari penelitian ini adalah $85 \%$ dari seluruh siswa mendapat nilai $\geq 75$.Hasil belajar dianalisis dengan analisis ketuntasan. Pada proses belajar mengajar dengan menggunakan model pembelajran koopeatif tipe NHT, pada siklus 1 dan 2 hasil belajar Matematika meningkat. Dari siswa yang berjumla 15 anak, sewaktu pra siklus siswa yang tuntas sebanyak 5 (33,33\%). Sedangkan yang belum tuntas berjumlah 10 siswa $(66,66 \%)$. Setelah diadakan penelitian tindakan kelas dengan menggunakan model pembelajaran kooperatif tipe NHT pada siklus 1 siswa yang tuntas belajar berjumlah 8 siswa $(53,33 \%)$ sedangkan yang belum tuntas dalam belajar berjumlah 7 siswa dengan nilai rata-rata 73,66. Pada siklus 2 siswa yang tuntas belajar adalah 13 siswa $(86,66 \%)$ sedangkan yang belum tuntas dalam belajr berjumlah 2 siswa $(13,33 \%)$ dengan nilai rata-rata 81,33 . Hasil penelitian ini menunjukkan bahwa melalui model pembelajaran kooperatif tipe NHT dapat meningkatkan hasil belajar Matematika pada siswa Kelas IV SD N 101212 Padang Bujur.
\end{abstract}

Kata Kunci: Model pembelajara Kooperatif Tipe Number Head Together (NHT), Hasil Belajar Matematika

\section{PENDAHULUAN}

Semakin berkembangnya teknologi informasi saat ini menyebabkan berbagai perubahan terjadi diberbagai lini kehidupan. Perkembangan juga merambah dalam dunia pendidikan. Berdasarkan hal tersebut, maka proses pendidikan haruslah dapat dijalankan sesuai dengan ketentuan yang bersifatmendasar bagi perkembangan ilmu pengetahuan termasuk proses pembelajaran yang mendukung perubahan tersebut dan sesuai dengan 
tujuan kurikulum. Pembelajaran yangberkualitas adalah pembelajaran yang dilakukan secara sistematis yaitu dilakukan di sekolah. Satu-satunya perbedaan antara pembelajaran yang dilakukan di sekolah dengan lingkungan lainnya adalah adanya tujuan pendidikan. Hasil belajar termasuk komponen pendidikan yang harus disesuaikan dengan tujuan pendidikan, karena hasil belajar diukur untuk mengetahui ketercapaian tujuan pendidikan melalui proses belajar mengajar.

Salah satu mata pelajaran yang wajib diberikan di SD adalah matematika. Shadiq (2014) menjelaskan bahwa menurut para ahli pendidikan matematika, matematika adalah ilmu yang membahas pola atau keteraturan (pattern) dan tingkatan (order). Sekali lagi, hal ini menunjukkan bahwa guru matematika harus memfasilitasi siswanya untuk belajar berpikir melalui keteraturan (pattern) yang ada. Pelajaran matematika sangat penting karena akan berpengaruh terhadap kehidupan siswa, misalnya untuk berfikir dan memecahkan suatu masalah yang dia hadapi. Akan tetatpi jika kita tinjau dilapangan maka bisa ditemukan masalah yang berkaitan dengan mata pelajaran matematika. Matematika merupakan salah satu matapelajaran di sekolah yang mendapatkan perhatian khusus oleh para guru, orangtua maupun anak. Walaupun menyadari hal tersebut faktanya masih terdapat anak yang belum dibekali kemampuan untuk berprestasi cemerlang di bidang matematika. Rendahnya minat siswa untuk menekuni matematika salah satunya disebabkan oleh adanya image yang mengganggu pikiran sebagian besar siswa bahwa matematika adalah pelajaran yang super rumit, rajanya pelajaran studi (Halim, 2009).

Model pembelajaran yang diterapkan saat ini oleh sebagian besar guru menggunakan model pembelajaran biasa, yang lebih terfokus pada guru. Inisiatif, informasi, pertanyaan, penugasan, umpan balik dan penilaian terpusat pada guru. Dalam kegiatan belajar siswa bekerja hanya berdasarkan pada perintah atau-tugas-tugas yang diberikan oleh guru sehingga kurang siswa untuk mendukung penguasaan materi pelajaran. Hal ini sesuai dengan pengalaman penulis di SD Negeri 101212 Padang Bujur kelas IV, terutama dalam mata pelajaran Matematika tentang sistem pemerintahan desa dan kecamatan dengan penguasaan materi masih rendah. Untuk itu perlu mendapat penanganan dan perhatian peneliti.

Pemberian tindakan dilakukan dengan menerapkan metode kooperatif Numbered Heads Together (NHT). Model pembelajaran kooperatif dikembangkan untuk mencapai hasil belajar salah satunya prestasi akademik (Suprijono, 2011). Metode kooperatif mampu membangkitkan motivasi siswa agar mampu berperan secara aktif dalam kegiatan pembelajaran (Hanze dan Berger, 2006). NHT merupakan teknik mengajar yang efektif dan efisien untuk meningkatkan prestasi belajar (Maheady, et al, 2006; Melati, 2011). Metode tersebut memberikan peluang kepada siswa untuk membangun pengetahuannya sendiri dan menggunakan konsepkonsep yang sudah dimiliki untuk memecahkan masalah secara kelompok. Kesuksesan kelompok ditentukan oleh peran anggota. Untuk meningkatkan prestasi kelompok, maka setiap anggota harus berprestasi.

Penerapan metode NHT dilakukan melalui empat tahap, yaitu penomoran, mengajukan pertanyaan, berpikir bersama, dan menjawab (Trianto, 2007). Dalam penerapannya, untuk membantu dalam penyampaian pelajaran demi tercapaianya tujuan belajar digunakan media buku saku. Buku saku memiliki beberapa kelebihan, diantaranya uraian bacaan yang relatif pendek pada setiap halamannya, ukuran buku yang relatif kecil sehingga mudah dibawa kemanapun dan dapat dimasukkan ke dalam saku, serta penyajian buku saku dilengkapi gambar dan warna sehingga memberikan tampilan yang menarik (Ami, dkk, 2012). 
Upaya Meningkatkan Hasil Belajar Matematika Dengan Menggunakan Model...

\section{METODE}

Metode penelitian yang digunakana dalam penelitian ini adalah penelitian tindakan kelas. Prosedur yang dilakukan dalam penelitian ini terdiri dari 2 siklus yang direncanakan, setiap siklus terdiri dari 4 tahap, yaitu tahap perencanaan, tahap pelaksanaan tindakan, tahap pengamatan (observasi) dan tahap refleksi.

1. Perbaikan Siklus I

a. Tahap Perencanaan yaitu: (1), Menyusun program pengajaran (RPP) (2), Menyiapkan materi pelajaran (3), Menyusun soal LKS

b. Tahap Pelaksanaan Tindakan, yaitu: (1), Menjelaskan materi pelajaran tentang system pemerintahan desa dan kecamtan (2), Memberikan kesempatan kepada siswa untuk mempersiapkan tugas yang telah dikerjakan (3), Diakhir pembelajaran guru bersama siswa menyimpulkan materi pelajaran dan memberikan tindak lanjut berupa PR

c. Tahap pengamatan (Observasi) yaitu: (1), Dalam pembelajaran, masih ada siswa yang kurang memperhatikan pelajaran (2), Siswa tidak dapat menyelesaikan tugas tepat waktu (3), Pemahaman siswa terhadap materi masih kurang

d. Tahap Refleksi yaitu: (1), Awal pembelajaran yang baik dapat meningkatkan semangat belajar (2), Menggunakan alat peraga berupa gambar untuk memudahkan pemahaman materi.

2. Perbaikan Siklus II

a. Tahap Perencanaan Perbaikan yaitu: (1), Meningkatkan pemahaman siswa terhadap materi pelajaran (2), Menyiapkan alat peraga (3), Menggunakan Model Pembelajara NHT (4), Memberi kesempatan kepada siswa untuk bertanya (5), Membuat soal evaluasi

b. Tahap Pelaksanaan Perbaikan yaitu: (1), Memberikan motivasi kepada siswa yang belum memahami materi pelajaran. (2), Menjelaskan materi pelajaran dengan menggunakan alat peraga berupa gambar dan memberi kesempatan siswa untuk menjawab peristiwa/gejala alam apa yang ada pada gambar (3), Memberikan lembar kerja soal kepada siswa (4), Siswa dan guru melakukan tanya jawab dan memberikan kesempatan kepada siswa untuk bertanya. (5), Diakhir pembelajaran guru bersama siswa menyimpulkan materi pelajaran, dan memberikan beberapa pertanyaan kepada siswa sebagai tes hasil belajar

c. Tahap Pengamatan yaitu: (1), Memberi penguatan kepada siswa yang dapat menyelesaikan tugas (2), Memberikan pujian kepada siswa yang dapat menjawab pertanyaan (3), Siswa semakin aktif dan termotivasi dalam belajar (4), Sudah melakukan Tanya jawab antara guru dan siswa

d. Tahap Refleksi yaitu: (1), Menganalisis data untuk menemukan keberhasilan pelaksanaan perbaikan pembelajaran (2), Menggunakan alat peraga berupa gambar dapat meningkatkan motivasi belajar dan hasil belajar siswa.

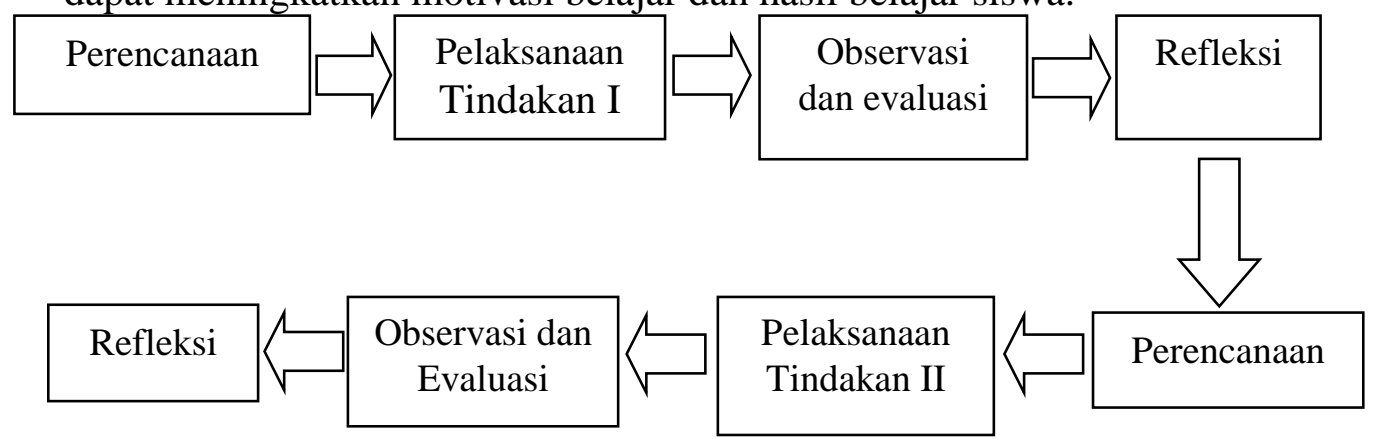

Gambar 1. Prosedur Pelaksanaan Penelitian Tindakan Kelas (PTK). 
Kriteri keberhasilan penelitian ditinjau dari kriteria ketuntasan belajar secara perorangan dan klasikal, yang dijabarkan sebagai berikut:

a. Seseorang siswa dikatakan telah tuntas belajar jika siswa telah mencapai skor $>65 \%$ atau $>65$.

$$
P P H=\frac{B}{N} \times 100 \% \quad \text { (Suherman, 2001:75) }
$$

Dimana: PPH : Persentase Penilaian Hasil

B : Skor yang diperoleh siswa

$\mathrm{N}$ : Skor maksimal

Dengan kriteria:

$0<\mathrm{PPH} \leq 65 \% \quad$ Siswa belum tuntas dalam belajar

$65<\mathrm{PPH} \leq 100 \% \quad$ Siswa sudah tuntas dalam belajar

Secara individual, siswa dikatakan telah tuntas belajar apabila DS $>65 \%$

b. Suatu kelas dikatakan tuntas belajar jila kelas tersebut terdapat $85 \%$ siswa yang telah mencapai daya serap DS $>65 \%$.

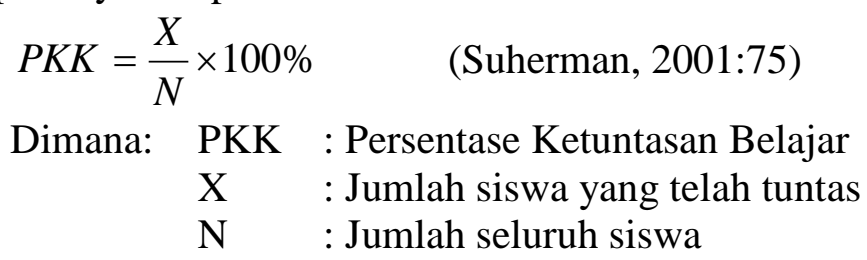

c. Menganalisa Hasil Observasi

$$
N=\frac{\text { skor yang didapat }}{\text { banyakobservasi }}
$$

Dimana:

$\mathrm{N}$ : Nilai Akhir

Adapun kriteria rata-rata penilaian akhir adalah:

$$
\begin{aligned}
& 1,0-1,5: \text { kurang } \\
& 1,6-2,5: \text { sedang } \\
& 2,6-3.5: \text { baik } \\
& 3,6-4,0: \text { sangat baik }
\end{aligned}
$$

\section{HASIL DAN PEMBAHASAN}

Pada saat pembelajaran prasiklus mata pelajaran Matematika kelas IV Semester I di SD Negeri No. 101212 Padang Bujur Kecamatan Sipirok hasilnya masih kurang memuaskan. Untuk lebih jelasnya dapat ilihat pada diagram berikut: 
Upaya Meningkatkan Hasil Belajar Matematika Dengan Menggunakan Model...

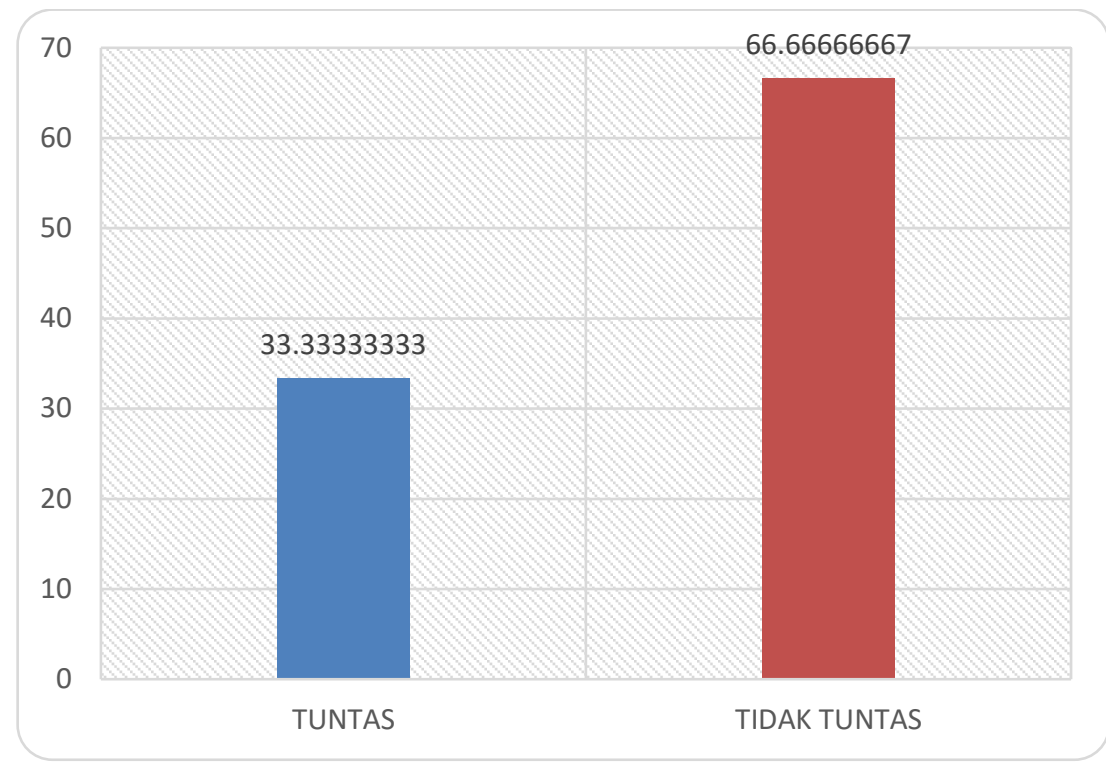

Gambar 1. Grafik Hasil Belajar Pra Siklus Siswa

Siswa yang belum tuntas dalam pembelajaran sebanyak 10 siswa, yang tuntas hanya 5 siswa dengan prosentase ketuntasan belajar adalah 33,33\%. Hal ini menunjukkan bahwa hasil belajar siswa masih rendah dalam penguasaan materi pembelajaran yang diberikan oleh guru. Maka peneliti perlu segera mengambil langkah untuk memperbaiki pembelajaran tersebut, agar siswa dapat memahami materi pembelajaran. Maka berdasarkan hasil para siklus, peneliti menyusun sebuah pembelajaran dengan memperhatikan kelemahan-kelemahan yang telah dianalisis. Pembelajaran didesain dengan menggunakan model pembelajaran kooperatif tipe number head together (NHT). Setelah dilakukan pembelajaran diperoleh hasil tes siklus I sebagai berikut.

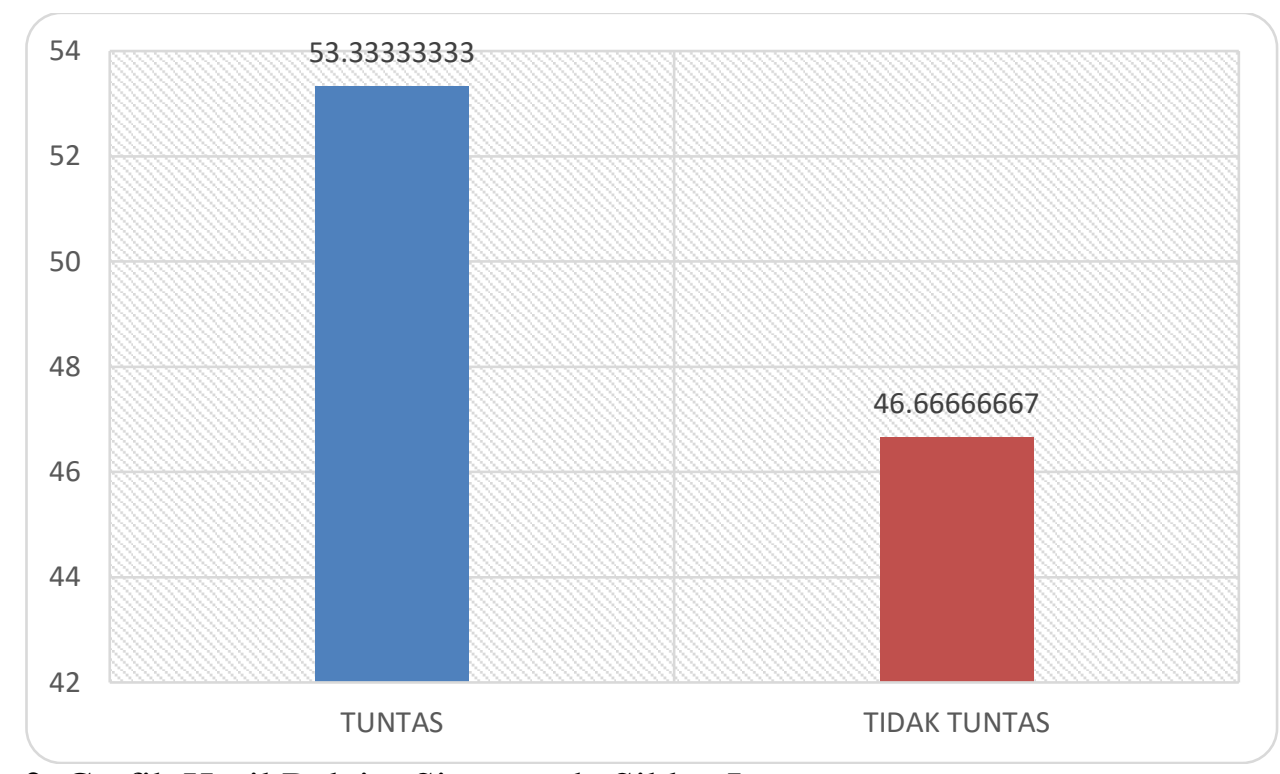

Gambar 2. Grafik Hasil Belajar Siswa pada Siklus I

Dari analisis hasil tes formatif siklus I dan gambar grafik di atas dalam pembelajaran Matematika rata-rata kelas 73,66 . Siswa yang belum tuntas dalam pembelajaran sebanyak 7 siswa, dan yang tuntas ada 8 siswa dengan prosentase ketuntasan belajar baru mencapai $53,33 \%$. Hal ini menunjukkan bahwa hasil prestasi siswa sudah ada kemajuan atau peningkatan prestasi siswa, akan tetapi masih perlu ditingkatkan agar siswa dapat 
menguasai materi pelajaran. Dengan demikian peneliti masih perlu segera mengambil langkah untuk memperbaiki pembelajaran tersebut, agar siswa dapat memahami materi sesuai dengan kompetensi yang harus dicapai dalam pembelajaran. Pada pelaksanaan perbaikan pembelajaran siklus I ada sebanyak 8 orang yang sudah tuntas dengan nilai 90 sebanyak 1, nilai 85 sebanyak 1 orang, 80 sebanyak 3 orang, dan nilai 75 sebanyak 3 orang. Dengan demikian ada sebanyak 7 orang lagi yang belum tuntas. Sesuai dengan hasil siklus I tersebut, maka peneliti perlu melaksanakn perbaikan pembelajaran siklus II. Berikut adalah grafik hasil perolehan siswa pada siklus II.

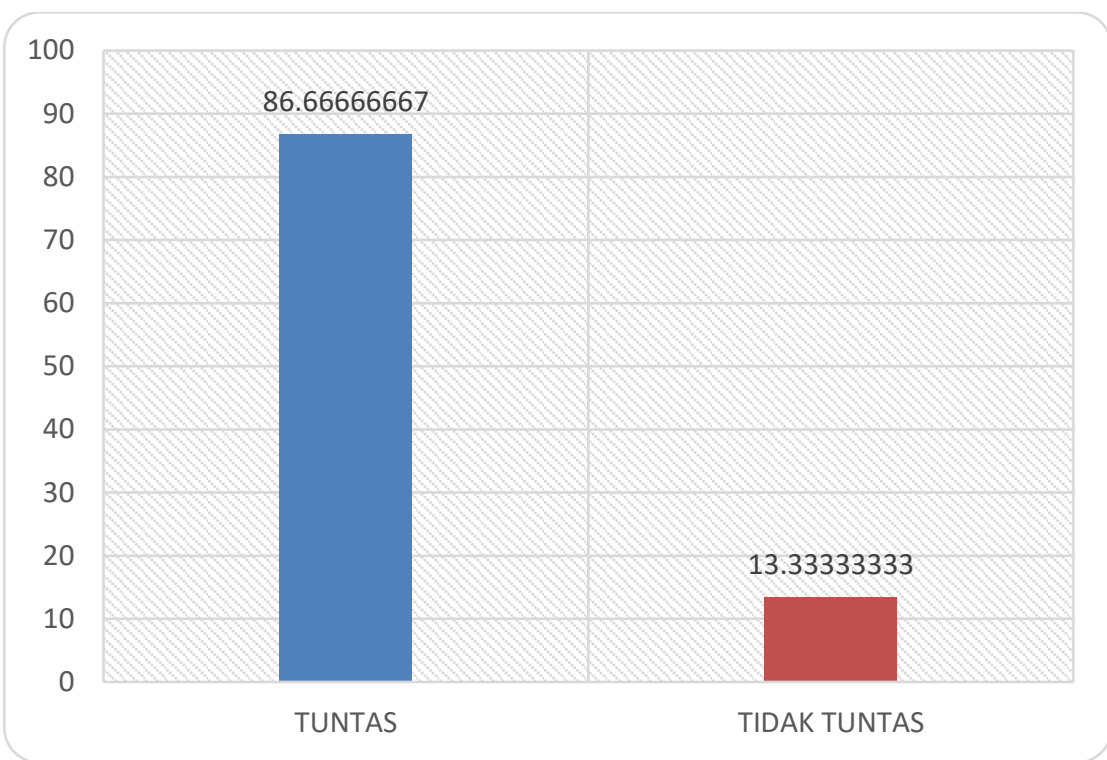

Gambar 3. Grafik Hasil belajar Siswa pada Siklus II

Dari pelaksanaan perbaikan pembelajaran siklus II. Pada akhirnya pembelajaran Matematika dikelas IV Semester I tahun pelajaran 2016/2017 di SD N 101212 Padang Bujur dapat berhasil dengan memuaskan, hanya ada dua siswa yang tidak tuntas. Setelah melalui kegiatan perbaikan pembelajaran siklus II maka hasil tes formatif pada akhir siklus II mengalami peningkatan yang signifikan. Pada pelaksanaan perbaikan pembelajaran siklus II belajar siswa semakin meningkat, dimana siswa secara langsung aktif untuk menemukan jawaban berdasarkan hasil kerja kelompok masing-masing. Dari jumlah siswa seluruhnya yaitu 13 orang tuntas dan 2 orang yang tidak tuntas. Dengan demikian hal ini menunjukkan adanya peningkatan hasil belajar siswa dalam memahami pembelajaran matematika materi pemerintahan desa dan kecamatan dengan menggunakan model pembelajaran kooperatif tipe number head together (NHT).

Berdasarkan hasil penelitian, sebelum diberi tindakan (prasiklus) rata-rata free test kelas adalah 69 dengan tingkat ketuntasan belajar 33,33\%. Hal ini dipengaruhi oleh belum adanya tindakan. Setelah diberi tindakan I menggunakan model pembelajaran kooperatif tipe NHT rata-rata nilai tes hasil belajar siklus I meningkat menjadi 73,66 dengan persentase ketuntasan 53,33\%. Namun masih perlu untuk ditingkatkan. Kemudian pemberian tindakan II, dimana pembelajaran masih tetap dengan model kooperatif tipe NHT diperoleh rata-rata siklus II siswa adalah 81 dengan persentase ketuntasan belajar $86,66 \%$. Siklus II mengalami peningkatan persentase ketuntasan karena kendala pada siklus I sudah mampu untuk diatasi lebih baik lagi oleh guru.

Salah satu faktor pendukung terjadinya peningkatan ini adalah positive interdependence, yaitu adanya ketergantungan positif. Anggota kelompok adalah bagian dari kelompok. Kesuksesan kelompok menjadi tanggung jawab anggota. Hal lain yang mendukung adalah adanya individual accountability, yaitu tanggungjawab anggota. 
Anggota kelompok yang menginginkan kelompoknya mendapat hasil terbaik harus memberikan kemampuan terbaiknya. Meskipun demikian, kelompok tidak didominasi oleh satu atau dua anggota. Setiap anggota memiliki hak dan kewajiban yang sama dalam equal partisipation. Hal ini juga ikut andil dalam tercapainya peningkatan tersebut.

Tahapan berpikir bersama dalam NHT mendukung anggota kelompok untuk mengenal dan mengembangkan aspek afektif yang meliputi sikap, minat, konsep diri, nilai, dan moral. Hal ini terlihat dari adanya tuntutan "menyatukan kepala." Dalam tahapan tersebut, setiap anggota menyatukan pendapatnya untuk memperoleh jawaban yang paling tepat dan meyakinkan setiap anggota mengetahui jawaban itu. Tahapan ini memberi dampak pada mereka untuk lebih bisa mengendalikan diri mereka dalam berinteraksi satu sama lain.

Tahapan tersebut mampu mendorong anggota untuk mengembangkan keterampilan sosial yang mereka miliki seperti kepemimpinan, kemampuan berkomunikasi, dan mempercayai orang lain. Hal ini dapat dilihat pada capaian aspek afektif yang diukur melalui angket. Berdasarkan penelitian diperoleh, persentase siswa yang memperoleh afektif tinggi $62,5 \%$ dan pada siklus II diperoleh 83,33\%.

\section{KESIMPULAN DAN SARAN \\ Kesimpulan}

Berdasarkan Hasil Penelitian perbaikan pembelajaan pada mata matematika di kelas IV SD N 101212 Padang Bujur dapat dikemukakan kesimpulan:

1. Pelaksanaan pembelajaran dengan menggunakanpembelajaran Number Head Together (NHT) dalam proses pembelajaran matematika dapat meningkatkan hasil belajar.

2. Pada pelaksanaan prasiklus ini nilai rata-rata hasil belajar yang diperoleh siswa kelas IV SD Negeri 101212 Padang Bujur pada mata pelajaran matematika adalah 69 dengan jumlah siswa yang tuntas 5 orang $(33,33 \%)$ yaitu 1 orang nilai 80,4 orang niai 75 .

3. Selanjutnya Pada pelaksanaan perbaikan pembelajaran siklus I ada sebanyak 8 orang yang sudah tuntas dengan nilai 90 sebanyak 1, nilai 85 sebanyak 1 orang, 80 sebanyak 3 orang, dan nilai 75 sebanyak 3 orang. Dengan demikian ada sebanyak 7 orang lagi yang belum tuntas.

4. Kemudian Pada pelaksanaan perbaikan pembelajaran siklus II belajar siswa semakin meningkat, dimana siswa secara langsung aktif untuk menemukan jawaban berdasarkan hasil kerja kelompok masingmasing. Dari jumlah siswa seluruhnya yaitu 13 orang tuntas dan 2 orang yang tidak tuntas. Dengan demikian hal ini menunjukkan adanya peningkatan hasil belajar siswa dalam memahami pembelajaran matematika dengan menggunakan model pembelajaran kooperatif tipe number head together (NHT).

\section{Saran}

Ada beberapa hal yang diahrapkan peneliti setelah menyelesaikan laporan perbaikan pembelajaran sebagai berikut:

1. Dalam proses pembelajaran dengan menggunakan pembelajaran kooperatif tipe NHT dapat meningkatkan hasil belajar siswa. Namun demikian diperlukan dukungan dari berbagai pihak, khusunya supervisor, kepala sekolah dan instansi terkait.

2. Guru hendaknya dapat melibatkan siswa berinteraksi aktif dalam pembelajaran, memberikan motifasi kepada siswa untuk belajar, memberikan kesempatan mengemukakan pendapat tentang apa yang belum dimengerti.

\section{DAFTAR PUSTAKA}

Ami, M. S., Susantini, E., dan Raharjo. 2012. Pengembangan Buku Saku Materi Sistem Ekskresi Manusia di SMA/MA Kelas XI. BioEdu. 1(2). 10-13. 
Halim, A. 2009. Matematika Hakikat dan Logika. Jakarta: A-ruz.

Hanze., Berger, R. 2006. Cooperative learning, motivational effects, and student characteristics: An experimental study comparing cooperative learning and direct instruction in 12th grade physics classes. Learning and Instruction. 17(2007), 29-41.

Maheady, L., Michielli-Pendl. J., Harper, G. F., dan Mallette, B. 2006. The Effects of Numbered Heads Together with and Without an Incentive Package on the Science Test Performance of a Diverse Group of Sixth Graders. Journal of Behavioral Education. 15(1), 25-39.

Melati, H. A. 2011. Meningkatkan Aktivitas dan Hasil Belajar Siswa SMAN 1 Sungai Ambawang Melalui Pembelajaran Model Advance Organizer Berlatar Numbered Heads Together (NHT) pada Materi Kelarutan dan Hasil Kali Kelarutan. Jurnal Visi Ilmu Pendidikan. 619- 630.

Soegito, E., Nurani. E. 2003. Kemampuan Proses Belajar. Jakarta : Universitas Terbuka.

Sudjana. 2005. Metode Statistika. Bandung: PT. Tarsito.

Suherman, E. 2001. EvaluasiProses dan Hasil Belajar Matematika. Jakarta: Universitas.

Suprijono, A. 2011. Cooperative Learning Teori dan Aplikasi PAIKEM. Yogyakarta: Pustaka Pelajar.

Trianto. 2007. Model-model Pembelajaran Inovatif dan Berorientasi Konstruktivistik. Jakarta: Prestasi Pustaka. 